\title{
PEMBUATAN ALAT PANTAU SUHU DAN KELEMBABAN UDARA BERBASIS SHORT MESSAGE SERVICE (SMS) MENGGUNAKAN AWE.2020
}

\section{Production of Monitoring Temperature and Humidity Device Based On Short Message Service (SMS) Using AWE.2020}

\author{
I Putu Wahyu Pranata Kusuma Jaya ${ }^{1}$, I Gusti Agung Widagda ${ }^{2 *}$ \\ ${ }^{1,2}$ Program Studi Fisika, Fakultas Matematika dan Ilmu Pengetahuan Alam, Universitas Udayana, Kampus \\ Bukit Jimbaran, Badung, Bali, Indonesia 80361 \\ Email:wahyupranata992@gmail.com,*igawidagda@unud.ac.id
}

\begin{abstract}
Abstrak - Telah berhasil dibuat sebuah alat yang dapat memantau suhu dan kelembaban udara melalui sebuah ponsel berbasis Short Message Service (SMS) dengan nama AWE.2020. Alat ini terdiri dari sensor suhu dan kelembaban DHT22, modul GSM SIM800L, dan mikrokontroler Arduino Uno. Hasil pembacaan suhu dan kelembaban dari sensor DHT22 diolah oleh mikrokontroler Arduino Uno dan hasilnya dikirimkan berupa SMS lewat modul GSM SIM800L. Untuk mengukur tingkat keakuratan dari alat rancangan (AWE.2020) telah dilakukan kalibrasi dengan alat standar AWS yang ada di Stasiun Klimatologi Jembrana, Bali. Beberapa parameter dipakai untuk mengukur tingkat keakuratan alat ukur ini yaitu analisis regresi dan uji-t statistik. Hasil pengamatan menunjukkan bahwa kinerja dari AWE.2020 ini sangat bergantung pada kualitas sinyal provider. Saat kondisi sinyal provider bagus, hasil uji-t dan analisis regresi alat ini menunjukan tingkat keakuratan yang tinggi. Demikian sebaliknya. Dari hasil pengamatan, serta uji statistik diperoleh bahwa alat tersebut akurat dan presisi untuk digunakan namun bergantung pada sinyal provider yang digunakan.
\end{abstract}

Kata kunci:AWE.2020, AWS, Suhu, Kelembaban Udara, Short Message Service (SMS).

\begin{abstract}
It has been successfully created a device that can monitor the temperature and humidity of air through a mobile-based Short Message Service (SMS) with the name is AWE.2020. This tool consists of DHT22 temperature and humidity sensor, a GSM SIM800L module, and an Arduino Uno microcontroller. The temperature and humidity readings will be processed by the Arduino Uno microcontroller and the result will be sent as an SMS via GSM SIM800L module. To measure the accuracy of the prototype device (AWE.2020) a calibration was done with existing standard AWS device at Jembrana Climatology Station, Bali. Several parameters are used to measure the accuracy of this measuring instrument, such as regression analysis and statistical t-test. The performance of AWE.2020 depends of the signal quality of the provider. When the signal is good, the result of t-test and regression analysis of this tool show a high degree of accuracy; and vice versa. From the observations, as well as statistical t-tests it was found that the tool was accurate and precise to use but depends on provider signal which is used for.
\end{abstract}

Key words: AWE.2020, AWS, Temperature, Air Humidity, Short Message Service (SMS).

\section{Pendahuluan}

Pertanian merupakan sektor yang paling besar menyumbang perekonomian masyarakat Indonesia. Hal tersebut dikarenakan sebagian besar masyarakat atau penduduk di Indonesia bekerja dibidang pertanian. Berdasarkan Badan Pusat Statistik (BPS), data pada Februari 2016, diperoleh 31,74\% angkatan kerja di Indonesia atau dengan jumlah sekitar 124 juta jiwa penduduk Indonesia bekerja pada sektor pertanian, sedangkan pada bulan Februari tahun 2017, BPS memperoleh data 31,86\% penduduk Indonesia bekerja pada sektor pertanian [1].

Salah satu faktor yang paling penting pada bidang pertanian adalah kualitas lahan pertanian. Semakin bagus lahan pertanian maka hasil pertanian juga akan semakin meningkat. Faktor paling penting yang mempengaruhi kualitas lahan pertanian yaitu, kelembaban udara dan suhu udara, dimana faktor tersebut juga merupakan kondisi lingkungan yang dapat berpengaruh besar terhadap pertumbuhan tanaman. Kerugian berupa gagal panen disebabkan oleh perubahan iklim seperti perubahan suhu dan kelembaban udara yang tidak menentu pada akhir-akhir ini, menjadi suatu kendala bagi para petani [2]. 
Permasalahan tersebut dapat terselesaikan dengan adanya sistem monitoring yang berbasis short message service (SMS) yang dapat memudahkan untuk mengukur dan memantau kondisi tanah dan tanaman. Semakin berkembangnya kemajuan bidang teknologi sekarang ini, hal tersebut dapat dilakukan dengan membuat suatu sistem atau alat yang berbasis SMS yang dapat memonitoring secara real time kondisi lahan pertanian dengan memanfaatkan sensor kelembaban tanah, kelembaban udara dan suhu sehingga dapat meminimalisir kemungkinan kerusakan pada hasil pertanian yang disebabkan oleh lahan pertanian kurang bagus karena tidak dilakukan monitoring terus menerus untuk mengetahui kualitas lahan pertanian mereka [1]. Maka dari itu, perlu dilakukan perancangan sebuah alat monitoring kelembaban udara dan suhu udara berbasis SMS, dimana nantinya akan dipantau melalui ponsel, sehingga dapat memudahkan para petani untuk memantau kualitas lahan pertanian mereka.

\section{Landasan Teori}

\subsection{Arduino Uno}

Arduino Uno adalah sebuah board mikrokontroler yang didasarkan pada Atmega328. Arduino Uno mempunyai 14 pin digital input/output, dan dapat dikontrol menggunakan bahasa $\mathrm{C}$ yang telah disederhanakan dengan fitur-fitur dalam library [3]. Selain itu dalam board Arduino sendiri sudah terdapat loader yang berupa USB sehingga memudahkan dalam menanamkan program pada Arduino. Arduino sebagai pengendali dari mikro single board bersifat open source, diturunkan dari wiring platform, dirancang untuk memudahkan penggunaan elektronik dalam berbagai bidang [4]. Board Arduino Uno secara fisik ditunjukan pada Gambar 1.

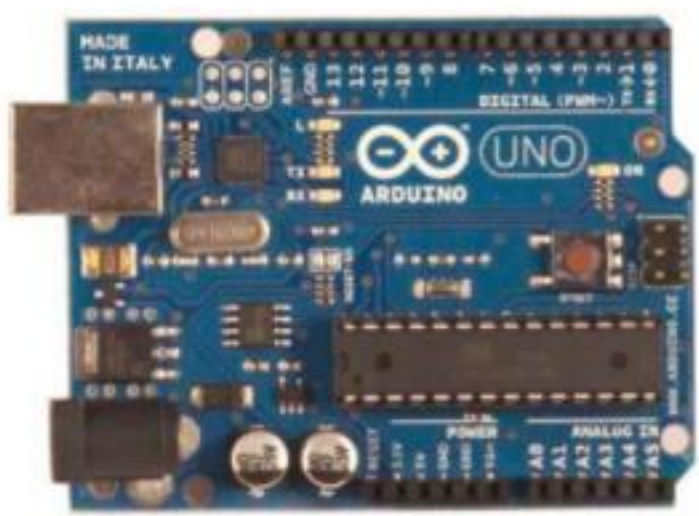

Gambar 1. Board Arduino Uno [5].

\subsection{Intergrated Inter Circuit (I2C)}

Intergrated Inter Circuit atau I2C adalah modul LCD yang dikendalikan secara serial sinkron dengan protokol I2C. Modul LCD dikendalikan secara paralel baik untuk jalur data maupun kontrolnya. Namun, jalur paralel memiliki kelemahan yaitu akan memakan banyak pin di sisi mikrokontroler, dimana setidaknya membutuhkan 6 atau 7 pin untuk mengendalikan sebuah modul LCD. Solusinya tentu saja I2C dimana dalam penggunaan I2C akan menghemat penggunaan jumlah pin pada mikrokontroler. Dengan menggunakan I2C hanya dibutuhkan dua pin yaitu untuk SDA dan SCL dan untuk pasokan daya dibutuhkan yaitu pin VCC dan GND untuk mengendalikan sebuah LCD. Bentuk fisik I2C dapat dilihat pada Gambar 2.

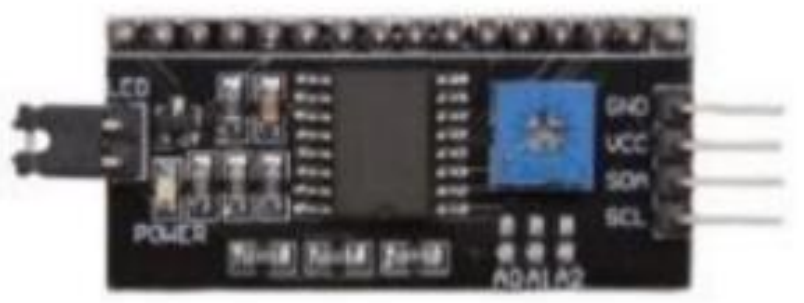

Gambar 2. Bentuk fisik I2C [6].

\subsection{Liquid Crystal Display (LCD)}


LCD atau Liquid Crystal Display adalah suatu perangkat yang digunakan sebagai media tampil dimana menggunakan kristal cair sebagai penampil utama. LCD memerlukan backlight untuk sumber cahayanya dikarenakan LCD tidak memancarkan pencahayaan apapun melainkan hanya merefleksikan dan mentransmisikan cahaya yang melewatinya. LCD yang digunakan dalam penelitian ini adalah LCD 16x2, I2C digunakan untuk mempermudah penggunaan pin yang sebagai sumber data pengontrol LCD oleh Arduino Uno [7]. Untuk lebih jelasnya, bagian-bagian LCD dapat dilihat pada Gambar 3.

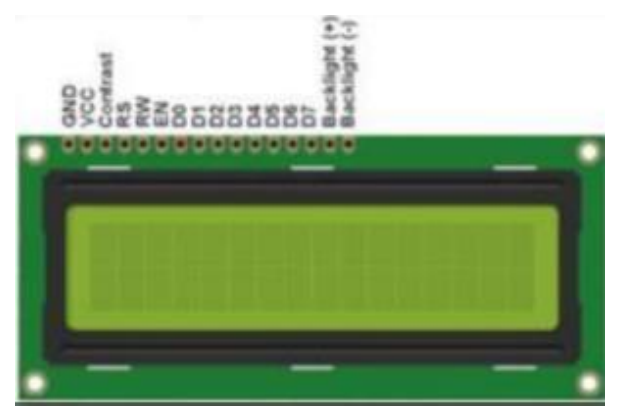

Gambar 3. Bentuk fisik LCD 16 x 2 [9].

\subsection{Modul GSM SIM800L}

Modul SIM800L GSM/GPRS adalah komponen elektronika yang berfungsi untuk berkomunikasi antara pemantau utama (dalam hal ini sistem monitoring) dengan Handphone. Sebuah Modul GSM SIM 800L terdiri dari beberapa bagian, diantaranya adalah lampu indikator, terminal daya, terminal kabel ke komputer, antena dan slot kartu mikro SIM. Modul GSM ini menggunakan ic chip SIM800. Tegangan ke VCC antara 3,7-4,2 VDC dan disarankan menggunakan 3,7 VDC agar tidak terjadi over voltage. Bekerja pada frekuensi jaringan GSM yaitu QuadBand (850 / 900 / 1800 / 1900Mhz) [8].Saat pertama dihubungkan dengan sistem, LED pada GSM SIM800L akan berkedip sekali per detik. Hal tersebut menandakan modul GSM SIM800L sedang mencari sinyal. Ketika LED berkedip sekali per 3 detik, maka GSM SIM800L siap digunakan, bentuk fisik modul GSM SIM800L ditunjukan pada Gambar 4. Tegangan masukan yang dibutuhkan pada GSM SIM800L ini berada pada interval 3,7-4,2 VDC. Karena tegangan yang diberikan oleh output Arduino adalah sebesar 5 VDC maka dibutuhkan pengonversi tegangan dari 5 VDC ke 3,7-4,2 VDC. Pengonversi tegangan yang dimaksud adalah regulator Step Down. Bentuk fisik dari regulator Step Down dapat dilihat pada Gambar 5.

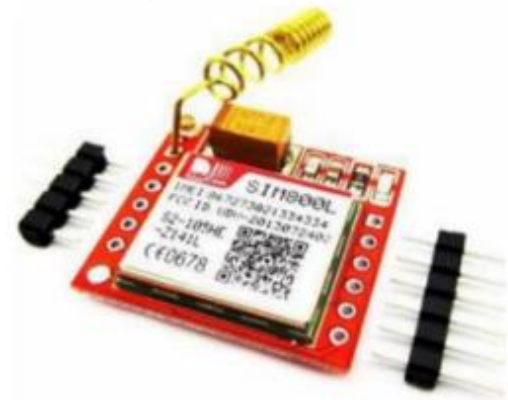

Gambar 4. Pin - out Modul GSM SIM800L [10].

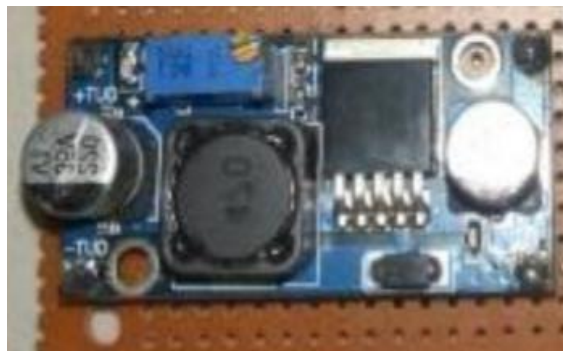

Gambar 5. Bentuk fisik Regulator Step Down [10].

\subsection{Sensor DHT22}


DHT22 adalah salah satu sensor yang dapat mengukur dua parameter lingkungan sekaligus, yakni suhu dan kelembaban udara (humidity). DHT22 (juga dikenal sebagai AM2302) adalah sensor suhu dan kelembaban seperti DHT11, namun memiliki kelebihan seperti output yang lebih akurat dan presisi dalam hasil pengukuran dibanding DHT11, rentang pengukuran suhu dan kelembaban yang lebih lebar dan mampu mentransmisikan sinyal output melewati kabel yang panjang (hingga $20 \mathrm{~m}$ ) sehingga cocok untuk ditempatkan di mana saja. Sensor DHT22 telah memiliki ADC (Analog to Digital Converter) di dalamnya sehingga keluaran data DHT22 sudah terkonversi dalam bentuk data digital dan tidak memerlukan ADC eksternal dalam pengolahan data pada mikrokontroler [11]. Bentuk fisik dari sensor DHT22 ditunjukkan pada Gambar 6.

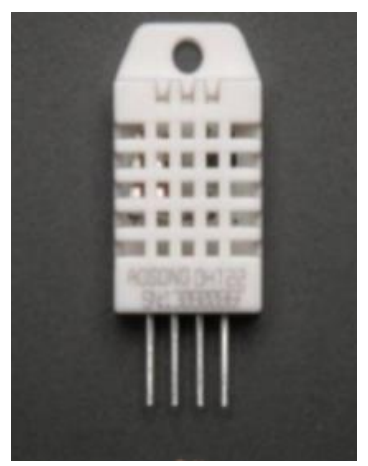

Gambar 6. Bentuk fisik Sensor DHT22 [12].

\section{Metode Penelitian}

\subsection{Perancangan Perangkat Keras (Hardware)}

Perancangan AWE.2020 digunakan Box sebagai tempat untuk instalasi LCD 16x2, Arduino Uno, regulator step down, dan modul GSM SIM800L. Modul DHT22 diletakan terpisah dengan jarak $130 \mathrm{~cm}$ dari Box. Adapun skematik perancangan AWE.2020 ditunjukan oleh Gambar 7. Instalasi dilakukan pada taman Alat Stasiun Klimatologi Jembrana.

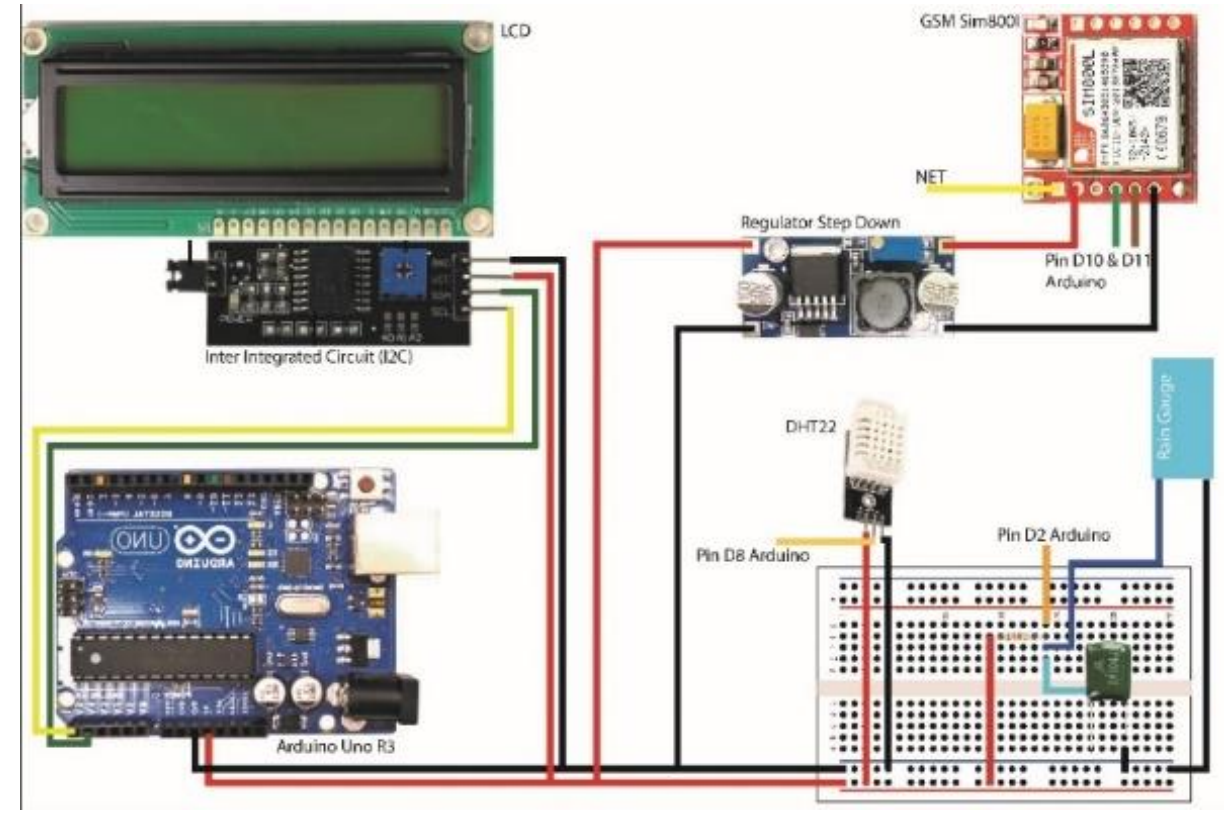

Gambar 7.Rangkaian Skematik AWE.2020.

\subsection{Pengambilan Data}

Pengambilan data dilakukan dengan mengamati data hasil pengukuran yang dilakukan oleh AWE.2020 yang terpantau melalui ponsel dengan data yang diperoleh dari alat standar yaitu AWS (Automatic Weather Station) yang dipasang di Stasiun Klimatologi Jembrana melalui monitor yang terdapat pada ruang observasi yang menampilkan data dari AWS Pengamatan dilakukan secara bersamaan dan hasilnya dicatat pada Microsoft Excel. Adapun diagram alir pengamatan suhu dan kelembaban oleh AWE.2020 ditunjukan pada Gambar 8. 


\subsection{Metode Analisis Data}

Setelah data diperoleh, kemudian dicari rata-rata hasil pengamatan serta standar deviasi untuk mengetahui seberapa besar penyimpangan yang terjadi pada pengukuran. Data dari alat AWE.2020 dan AWS, kemudian diuji secara statistik dengan metode uji-t pada program Microsoft Excel untuk memperoleh kepresisian alat AWE.2020, dan untuk mencari keakuratan alat AWE.2020 dilakukan dengan metode regresi. Regresi adalah sebuah metode untuk mendapatkan fungsi pendekatan dari sekumpulan titik-titik data, kemudian data diolah dengan metode regresi linier. Regresi linier adalah metode untuk mendapatkan fungsi pendekatan yang berbentuk linier dari sekumpulan titik data $\left(\mathrm{x}_{\mathrm{n}}, \mathrm{y}_{\mathrm{n}}\right)$. Persamaan ini menyatakan sebuah garis dengan gradien $m$ dan melewati titik $(0, c)$. Dalam regresi linier, terdapat istilah koefisien determinasi $\left(\mathrm{R}^{2}\right)$, yang menunjukkan seberapa besar variabel $\mathrm{x}$ mempengaruhi variabel $\mathrm{y}$.

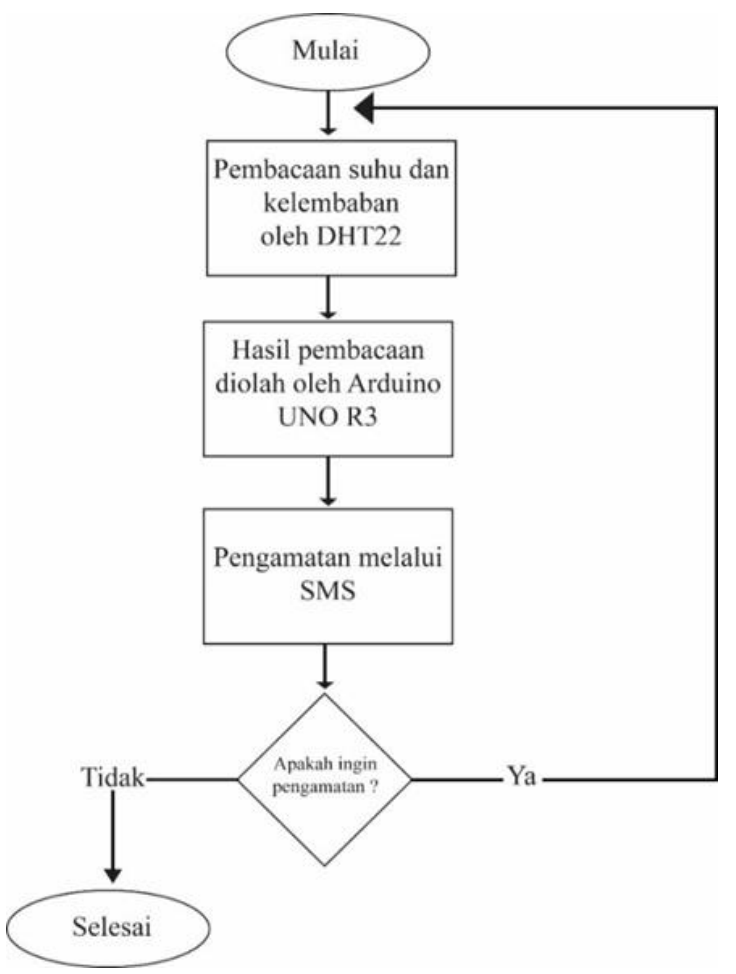

Gambar 8. Diagram alir (flowchart) pengamatan suhu dan kelembaban AWE.2020.

\section{Hasil Dan Pembahasan}

\subsection{Hasil}

Hasil yang diperoleh dari penelitian ini adalah alat yang dapat digunakan untuk memantau suhu dan kelembaban melalui ponsel atau smartphone melalui SMS. Nilai rata-rata dan standar deviasi dari hasil pengukuran AWS dan AWE.2020 disajikan pada Tabel 1 dan Tabel 2.

Tabel 1. Hasil rata-rata dan standar deviasi suhu AWS dan AWE.2020.

\begin{tabular}{clcc}
\hline & & \multicolumn{2}{c}{$(\mathrm{T} \pm \Delta \mathrm{T})\left({ }^{\circ} \mathrm{C}\right)$} \\
\cline { 3 - 4 } No & \multicolumn{1}{c}{ Hari, Tanggal } & AWS & AWE.2020 \\
\hline 1 & Kamis, 30 Januari 2020 & $(28,54 \pm 2,68)$ & $(28,51 \pm 2,73)$ \\
2 & Sabtu, 1 Februari 2020 & $(30,52 \pm 1,72)$ & $(30,48 \pm 1,74)$ \\
3 & Minggu, 2 Februari 2020 & $(29,50 \pm 2,20)$ & $(29,49 \pm 2,23)$ \\
4 & Senin, 3 Februari 2020 & $(29,31 \pm 1,48)$ & $(30,99 \pm 1,20)$ \\
5 & Selasa, 4 Februari 2020 & $(28,64 \pm 2,12)$ & $(31,47 \pm 1,22)$ \\
6 & Rabu, 5 Februari 2020 & $(31,80 \pm 1,05)$ & $(31,76 \pm 1,06)$ \\
\hline
\end{tabular}

Untuk mengetahui apakah ada perbedaan yang signifikan atau tidak, antara hasil pengukuran alat ukur yang dibuat dengan alat ukur referensi maka dilakukan uji statistik dengan uji-t dengan hipotesis penelitian, bahwa hasil pengukuran oleh alat ukur yang dibuat AWE.2020 dan referensi/standar AWS secara rata-rata 
adalah sama $\left(\mu_{1}=\mu_{2}\right)$. Dengan tingkat kepercayaan $95 \%$ atau tingkat signifikansi 0,05 hasil uji-t ini memperlihatkan apakah nilai $t_{\text {hitung }}$ lebih besar atau lebih kecil dari $t_{\text {tabel }}$. Apabila $t_{\text {hitung }}$ lebih besar dari pada $t_{\text {tabel }}$ maka terdapat perbedaan yang signifikan antara hasil pengukuran alat AWS dan AWE.2020, sebaliknya apabila $t_{\text {hitung }}$ lebih kecil dari pada $t_{\text {tabel }}$ maka tidak terdapat perbedaan yang signifikan antara hasil pengukuran alat AWS dan AWE.2020. Penyimpangan terjadi untuk pengukuran suhu dan kelembaban pada tanggal 3 dan 4 Februari 2020. Sebagai contoh pada tanggal 4 Februari 2020 untuk pengukuran suhu diperoleh nilai $t_{\text {hitung }}$ sebesar 8,051550363 dan nilai $t_{\text {tabel }}$ sebesar 1,991254395, menunujukan bahwa nilai $t_{\text {hitung }}$ lebih besar dari pada nilai $t_{\text {tabel }}$ maka perlu dilakukan kalibrasi. Hasil persamaan kalibrasi dan nilai $\mathrm{R}^{2}$ ditunjukkan pada Tabel 3 dan Tabel 4.

Tabel 2. Hasil rata-rata dan standar deviasi kelembaban AWS dan AWE.2020.

\begin{tabular}{clcc}
\hline & & \multicolumn{2}{c}{$(\mathrm{H} \pm \Delta \mathrm{H})(\%)$} \\
\cline { 3 - 4 } No & \multicolumn{1}{c}{ Hari, Tanggal } & AWS & AWE.2020 \\
\hline 1 & Kamis, 30 Januari 2020 & $(82,37 \pm 12,41)$ & $(80,18 \pm 10,42)$ \\
2 & Sabtu, 1 Februari 2020 & $(69,57 \pm 8,21)$ & $(69,29 \pm 7,80)$ \\
3 & Minggu, 2 Februari 2020 & $(75,97 \pm 9,79)$ & $(74,83 \pm 7,78)$ \\
4 & Senin, 3 Februari 2020 & $(79,52 \pm 7,99)$ & $(69,52 \pm 5,87)$ \\
5 & Selasa, 4 Februari 2020 & $(69,64 \pm 7,88)$ & $(62,64 \pm 5,01)$ \\
6 & Rabu, 5 Februari 2020 & $(63,56 \pm 5,00)$ & $(63,34 \pm 4,81)$ \\
\hline
\end{tabular}

Tabel 3. Hasil Uji Regresi pada pengukuran suhu.

\begin{tabular}{cccc}
\hline No & Hari, Tanggal & Persamaan Kalibrasi & nilai $\mathrm{R}^{2}$ \\
\hline 1 & Senin, 3 Februari 2020 & $\mathrm{y}=-0,7172 \mathrm{x}+52,018$ & $\mathrm{R}^{2}=0,7767$ \\
2 & Selasa, 4 Februari 2020 & $\mathrm{y}=-0,4619 \mathrm{x}+44,698$ & $\mathrm{R}^{2}=0,6405$
\end{tabular}

Tabel 4. Hasil Uji Regresi pada pengukuran kelembaban.

\begin{tabular}{cccc}
\hline No & Hari, Tanggal & Persamaan Kalibrasi & nilai $\mathrm{R}^{2}$ \\
\hline 1 & Senin, 3 Februari 2020 & $\mathrm{y}=-0,5772 \mathrm{x}+115,41$ & $\mathrm{R}^{2}=0,6172$ \\
2 & Selasa, 4 Februari 2020 & $\mathrm{y}=-0,4733 \mathrm{x}+95,608$ & $\mathrm{R}^{2}=0,5532$ \\
\hline
\end{tabular}

Pada penggunaan alat ukur hasil buatan, untuk mendapatkan nilai yang sesungguhnya maka nilai hasil pengukuran dimasukkan ke dalam persamaan kalibrasinya.

\subsection{Pembahasan}

Telah dilakukan pengukuran selama 6 hari dari tanggal 30 Januari hingga 5 Februari 2020 terhadap suhu dan kelembaban dengan alat AWE.2020 hasil rancangan, dan alat BMKG yaitu AWS. AWE.2020 merupakan alat yang berfokus dalam proses pembacaan suhu dan kelembaban. Sensor yang digunakan untuk pembacaan suhu dan kelembaban yakni modul DHT22 dan diproses oleh mikrokontroler Arduino Uno yang nantinya data hasil pembacaan ditampilkan pada LCD 16X2 serta pengiriman data ke ponsel dilakukan oleh modul GSM SIM800L. Setelah hasil pengukuran diperoleh, kemudian diuji statistik dengan uji-t dua arah untuk mengetahui apakah ada perbedaan yang signifikan atau tidak, antara hasil pengukuran alat ukur yang dibuat dengan alat ukur referensi dengan tingkat kepercayaan $95 \%$ atau tingkat signifikansi 0,05 . Dari hasil uji-t ini dilihat apakah nilai $t_{\text {hitung }}$ lebih besar atau lebih kecil dari $t_{\text {tabel }}$. Apabila $t_{\text {hitung }}$ lebih besar dari pada $t_{\text {tabel }}$ maka terdapat perbedaan yang signifikan antara pengukuran AWS dan AWE.2020, sebaliknya apabila $\mathrm{t}_{\text {hitung }}$ lebih kecil dari pada $t_{\text {tabel }}$ maka tidak terdapat perbedaan yang signifikan antara pengukuran AWS dan AWE.2020.

Berdasarkan hasil analisis, secara keseluruhan nilai $t_{\text {hitung }}$ lebih kecil dari pada $t_{\text {tabel }}$ namun terjadi penyimpangan pada tanggal 3 dan 4 Februari 2020 yang mengakibatkan nilai $t_{\text {hitung }}$ lebih besar dari $t_{\text {tabel }}$, yang berarti terdapat perbedaan yang signifikan antara hasil pengukuran alat AWS dan AWE.2020. Pada Tabel 3 dan Tabel 4 diperlihatkan nilai $\mathrm{R}^{2}$ menjauhi angka 1 yang berarti terjadi penurunan tingkat akurasi AWE.2020. Hal ini disebabkan karena pengiriman data melalui SMS mengalami gangguan yang disebabkan oleh sinyal dari provider yang digunakan. Proses pengiriman SMS menggunakan Modul GSM SIM800L membutuhkan delay sekitar 1-5 detik ketika kondisi sinyal baik, sedangkan saat kondisi sinyal kurang baik proses pengiriman SMS membutuhkan delay hingga mencapai 20 detik, tergantung tingkat kekuatan sinyal yang ada 
pada daerah tersebut [13]. Seperti yang diketahui, suhu dan kelembaban merupakan parameter yang bersifat dinamis. Sehingga, dalam interval delay tersebut suhu dan kelembaban dapat mengalami perubahan yang cukup signifikan. Maka dari itu alat AWE.2020 adalah alat yang akurat dan presisi namun bergantung pada sinyal provider yang digunakan. Semakin bagus sinyal providernya maka data yang akan dikirimkan semakin akurat atau real time dan alat juga semakin presisi sehingga penyimpangan dapat diminimalisir dan nantinya alat ini dapat digunakan oleh para petani dalam memantau keadaan lahan petani secara lebih akurat dan efisien.

\section{Kesimpulan}

Berdasarkan pembahasan di atas, dapat disimpulkan bahwa komponen-komponen yang dibutuhkan dalam merancang sistem monitoring suhu dan kelembaban berbasis SMS adalah Arduino Uno, modul DHT22, dan modul GSM SIM800L. Dari hasil pengamatan yang dilakukan selama 6 hari serta analisis statistik dengan ujit, terjadi penyimpangan pada tanggal 3 dan 4 Februari 2020, dimana $t_{\text {hitung }}$ lebih besar dari $t_{\text {tabel}}$, dan setelah dilakukan kalibrasi didapat koefisien determinasinya menjauhi angka 1 yang disebabkan oleh gangguan sinyal provider. Maka dari itu alat AWE.2020 adalah alat yang akurat dan presisi namun bergantung pada sinyal provider yang digunakan. Semakin bagus sinyal providernya maka data yang akan dikirimkan semakin akurat atau real time dan alat juga semakin presisi sehingga penyimpangan dapat diminimalisir dan nantinya alat ini dapat digunakan oleh para petani dalam memantau keadaan lahan petani secara lebih akurat dan efisien.

\section{Ucapan Terima Kasih}

Penulis mengucapkan terimakasih pada pihak Stasiun Klimatologi Jembrana yang telah memberikan bantuan berupa fasilitas dalam penelitian ini. Serta staf dosen bidang minat Elektronika, Instrumentasi, dan Komputasi, Program Studi Fisika, FMIPA, UNUD yang telah memberikan saran serta masukan terkait penelitian ini.

\section{Daftar Pustaka}

[1] A. B. Setyawan, M. H. H. Ichsan, G. E. Setyawan, Sistem Monitoring Kelembaban Tanah, Kelembaban Udara, Dan Suhu Pada Lahan Pertanian Menggunakan Protokol MQTT, Jurnal Pengembangan Teknologi Infoemasi dan Ilmu Komputer, Vol. 2, No. 12, 2018, pp. 7502-7508.

[2] S. Wahono, Sugiyanto, E. Yohana, Eksperimen Pengaturan Suhu Dan Kelembaban Pada Rumah Tanaman (Greenhouse) Dengan Sistem Humidifikasi, Jurnal Teknik Mesin S-1, Vol. 2, No. 1, 2014, pp. 49-56.

[3] Y. Mochtiarsa, B. Supriadi, Rancangan Kendali Lampu Menggunakan Mikrokontroller ATMega328 Berbasis Sensor Getar,Jurnal Informatika SIMANTIK, Vol. 1, No. 1, 2016, pp. 40-44.

[4] I. B. D. Kesuma, M. Sudarma, Swamardika, Rancang Bangun Sistem Pengaman Berbasis Arduino Uno, E-Journal SPEKTRUM, Vol. 3, No. 2,2016, pp. 89-92.

[5] H. I. Islam, N. Nabilah, S. S. Atsaurry, D. H. Saputra, G. M. Pradipta, A. Kurniawan, H. Syafutra, Irmansyah, Irzaman, Sistem Kendali Suhu Dan Pemantauan Kelembaban Udara Ruangan Berbasis Arduino Uno Dengan Menggunakan Sensor DHT22 Dan Passive Infrared (PIR), Prosiding Seminar Nasional Fisika, Vol. 5, 2016, pp. 119-124.

[6] G. Prasidya, R. Sitepu, W. Andyardja, Mesin Peniris Keripik Goreng Berbasis Motor Listrik Dan Mikrokontroler, Widya Teknik, Vol. 18, No. 1, 2019, pp. 28-35.

[7] I. W. E. Prastia, I. W. A. Wijaya, I. W.Sukerayasa, Rancang Bangun Monitoring Level Muka Air Tanah Di Perkebunan Lahan Gambut Menggunakan SMS Sebagai Pengirim Informasi Data Berbasis Mikrokontroler, Jurnal Spektrum, Vol. 6, No. 1, 2019, pp. 62-68.

[8] D. Andesta, R. Ferdian, Sistem Keamanan Sepeda Motor Berbasis Mikrokontroler dan Modul GSM, JITCE (Journal of Information Technology and Computer Engineering), Vol. 2, No. 2, 2018, pp. 51-63.

[9] M. Khaery, A. H. Pratama, P. Wipradnyana, A. A. N. Gunawan, Perancangan Alat Ukur Tekanan Udara Menggunakan Sensor Barometric Pressure 280 (BMP280) Berbasis Arduino Uno, Buletin Fisika, vol. 21, No. 1, 2020, pp. 14-19.

[10] S. Mulyati, Sumardi, Internet of Things (IOT) Pada Prototipe Pendeteksikebocoran Gas Berbasis MQ-2 dan SIM800L, Jurnal Teknik: Universitas Muhammadiyah Tanggerang, vol. 7, No. 2, 2018, pp. 64-72.

[11] Siswanto, I.Rojikin, W.Gata, Pemanfaatan Sensor Suhu DHT-22, Ultrasonik HC-SR04 Untuk Mengendalikan Kolam Dengan Notifikasi Email, JURNAL RESTI (Rekayasa Sistem dan Teknologi Informasi), Vol. 3, No. 3, 2017, pp. 544-551. 
[12] F. Puspasari, T. P. Satya, U. Y. Oktiawati, I. Fahrurrozi, H. Prisyanti, Analisis Akurasi Sistem Sensor DHT22 berbasis Arduino terhadap Thermohygrometer Standar, Jurnal Fisika Dan Aplikasinya, Vol. 16, No. 1, 2020, pp. 40-45.

[13] C. A. Maulidia, Alarm Peringatan Dini Potensi Banjir Berbasis Arduino 2560 Dengan Sensor Ultrasonic, Ubiquitous: Computers and its Applications Journal, Vol. 2, No. 1, 2019, pp. 21-28. 